\title{
END OF AN ERA? \\ THE DECLINE OF STUDENT PRESS \\ RIGHTS IN THE WAKE OF \\ HAZELWOOD SCHOOL \\ DISTRICT V. KUHLMEIER
}

\author{
J. MARC Abrams* \\ S. MARK GOODMAN**
}

\begin{abstract}
Almost twenty years ago, in a case involving the use of black armbands by high-school and junior-high-school students to express their opposition to the Vietnanı War, the Supreme Court stated: "It can hardly be argued that either students or teachers shed their constitutional rights to freedoin of speech or expression at the schoolhouse gate." Since that statement in 1969, alinost every court facing a question of student press rights has started its analysis with the Tinker v. Des Moines Independent Community School District decision and found student journalisin entitled to extensive first aniendinent protection.

Many courts, in grantimg such protections to the student press, have based their analysis on the "public forum doctrine."2 The Supreme Court developed this doctrine to ensure that once the state estabhished a "forum" for public discourse or expression, it would not censor speech or speakers absent highly compelling circumstances. ${ }^{3}$ As such, the doctrine has had a logical application to school-sponsored student newspapers, which provide avenues for the expression of student news and view-

* A.B., Wesleyan University; M.A., J.D., University of Michigan; Associate, Schnader, Harrison, Segal \& Lewis; Treasurer and former Executive Director, Student Press Law Center.

* B.J., University of Missonri; J.D., Duke University; Executive Director, Student Press Law Center.

1. Tinker v. Des Moines Indep. Conınıunity School Dist., 393 U.S. 503, 506 (1969).

2. See, e.g., Stanton v. Brunswick School Dep't, 577 F. Snpp. 1560, 1570-71 (D. Me. 1984); Gambino v. Fairfax County School Bd., 429 F. Supp. 731, 734 (E.D. Va.), aff'd per curiam, 564 F.2d 157, 158 (4th Cir. 1977); Panarella v. Birenbaum, 37 A.D.2d 987, 988, 327 N.Y.S.2d 755, 757 (1971), aff'd, 32 N.Y.2d 108, 296 N.E.2d 238, 343 N.Y.S.2d 333 (1973). Other courts have applied a forun analysis without specifically referring to it as such. See, e.g., Schiff v. Williams, 519 F.2d 257, 260-61 (5th Cir. 1975); Joyner v. Whiting, 477 F.2d 456, 460-61 (4th Cir. 1973); Bazaar v. Fortune, 476 F.2d 570, 575-80, aff'd as modified en banc per curiam, 489 F.2d 225 (5th Cir. 1973), cert. denied, 416 U.S. 995 (1974); Korn v. Elkins, 317 F. Supp. 138, 142-43 (D. Md. 1970); Zncker v. Panitz, 299 F. Supp. 102, 105 (S.D.IN.Y. 1969); Dickey v. Alabama State Bd. of Educ., 273 F. Supp. 613, 617-18 (M.D. Ala. 1967), vacated as moot sub nom. Troy State Univ. v. Dickey, 402 F.2d 515 (5th Cir. 1968).
\end{abstract}

3. Comelius v. NAACP Legal Defense \& Educ. Fnnd, 473 U.S. 788, 800 (1985). 
points. Thus, recognizing that school authorities' suppression of content essentially denies access to the pages of a student newspaper, courts have relied on the analysis also applied to public auditoriums ${ }^{4}$ and public university facilities. ${ }^{5}$

On January 13, 1988, lowever, the Supreme Court announced its decision in Hazelwood School District v. Kuhlmeier, ${ }^{6}$ which sharply limited the rights of students operating newspapers as part of a public school curriculum. As we will discuss below, ${ }^{7}$ Kuhlmeier eviscerates the Suprene Court's decision in Tinker, overrules inany lower-court decisions protective of the student press, and curtails student press rights established for well over a generation. The decision is also notable, however, for what it does not say, and because of that, some avenues for free expression by higli-school students remain. Although Kuhlmeier dealt witl a school-sponsored newspaper, it also casts uncertainty upon the status of independently run student newspapers and student newspapers at the college level. We will argue that the Kuhlmeier decision affects neither of these types of newspapers. The first amendment protections afforded these newspapers retain the vitality derived from the history of student press litigation in the past twenty years.

\section{Student Press First Amendment Rights, 1969-1988}

Nearly twenty years ago, the Supreme Court first explicitly recognized that public school students enjoy first amendment protections. ${ }^{8}$ The decision in Tinker involved synibolic expression in a higli school and a jumior high sclool, but the Supreme Court and other courts subsequently applied Tinker's principles to cases involving the student press at the high-school and college levels. ${ }^{9}$

In contexts other than the student press, the Court uses a "forum" analysis to determine when the government's niterest in restricting use of its property or facilities to an intended purpose outweighs the interest of those wishing to use the property or facilities for other purposes. ${ }^{10}$ The Court has stated that "a public forum may be created by government designation of a place or channel of communication for use by the public at large for assembly and speech, for use by certain speakers, or for the

4. See Southeastern Promotions, Ltd. v. Conrad, 420 U.S. 546 (1975).

5. See Widmar v. Vincent, 454 U.S. 263 (1981).

6. 108 S. Ct. 562 (1988).

7. See infra notes 90-113 and accompanying text.

8. Tinker v. Des Moines Indep. Community School Dist., 393 U.S. 503 (1969).

9. See, e.g., Papish v. Board of Curators, 410 U.S. 667 (1973) (college); Fujishima v. Board of Educ., 460 F.2d 1355 (7th Cir. 1972) (high school); Gambino v. Fairfax County School Bd., 429 F. Supp. 731 (E.D. Va.) (high school), aff'd per curiam, 564 F.2d 157 (4th Cir. 1977).

10. Cornelius v. NAACP Legal Defense \& Educ. Fund, 473 U.S. 788, 800 (1985). 
discussion of certain subjects."11 Once a state establislies a "public forum," it can restrict the expression that occurs there only when it can demonstrate a compelling state imterest and when the restriction is narrowly tailored to serve that interest. ${ }^{12}$ Thus, for example, if a city were to allow plays, speeclies, or meetings at a civic auditorium, that auditorium would be a public forum, and the city would violate the Constitution if it denied the auditorium's use for the performance of a play only because the play offended city officials. ${ }^{13}$ Courts also recognize scliool auditoriums, airports, and city parks as public forums, and have protected the riglit of sucli groups as the Hare Krishnas or the Nazi party to engage in expressive activities in those forums free of government censorship. ${ }^{14}$

Furtlier, the Supreine Court has consistently and unambiguously stated that prior restraints on expression are among the acts inost disfavored under the Constitution. ${ }^{15}$ This disfavor lias been, presumptively, no less true in the context of our nation's public schools. ${ }^{16}$

After Tinker, the Supreme Court lianded down several decisions dealing with the free speech rights of students. While all but one of these cases involved college students, the rules announced seemed equally applicable in the higli-scliool setting. In a 1972 case, Healy v. James, the Court held that a college could not refuse to recognize a group inerely because the college disagreed with the group's philosophy or had an undocumented fear of sclool disruption. ${ }^{17}$ In Papish v. Board of Curators, ${ }^{18}$ decided a year later, a college expelled a student for distributing a highly offensive newspaper on cainpus. The paper carried a political cartoon, which depicted policemen raping the Statue of Liberty and the Goddess of Justice, and a headline announcing "Motlierfucker Acquitter." In concluding tliat the expulsion violated the student's first amendment riglits, tlie Court found that the newspaper was not "obscene" and

11. Id. at 802 .

12. Perry Educ. Ass'n v. Perry Local Educators' Ass'n, 460 U.S. 37, 45 (1983).

13. See id.

14. National Socialist White People's Party v. Ringers, 473 F.2d 1010, 1015, 1019 (4th Cir. 1973) (school board may not prevent American Nazi Party from renting public school auditorium absent real threat to property or good order); Fernandes v. Limmer, 465 F. Supp. 493, 501 (N.D. Tex. 1979) (Hare Krishnas may solicit charitable contributions in airport terminal buildings), modified, 663 F.2d 619 (5th Cir. 1981), cert. dismissed, 458 U.S. 1124 (1982); Collin v. Smith, 447 F. Supp. 676, 685-86 (N.D. IIl.) (city may not abridge Nazi group's right to assemble in city park by requiring group to obtain insurance-unreasonable financial burden on exercise of its first amendment rights), aff'd, 578 F.2d 1197 (7th Cir.), cert. denied, 439 U.S. 916 (1978).

15. E.g., Nebraska Press Ass'n v. Stuart, 427 U.S. 539, 559 (1976); Bantam Books, Inc. v. Sullivan, 372 U.S. 58, 70 (1963).

16. See Tinker v. Des Moines Indep. Community School Dist., 393 U.S. 503 (1969).

17. 408 U.S. $169,187-91$ (1972).

18. 410 U.S. 667 (1973). 
that it was not likely to cause a disruption of the school, and therefore held that it could not be censored. ${ }^{19}$ In a 1981 case, Widmar $v$. Vincent, the Supreme Court held that a state university's pohicy prohibitimg the use of otherwise generally available school facilities for religious teaching or workshops violated students' rights to freedom of speech and association. ${ }^{20}$

Other courts also recognized the existence of public forums in schools and curtailed school censorship of activities. ${ }^{21}$ These courts imphicitly recognized that the status of a student activity as curricular or extracurricular, school-sponsored or student-sponsored, was irrelevant if a forum existed. ${ }^{22}$ One court stated that labeling an outlet for student expression an "imstructional tool" would not allow school administrators unbridled control when a forum in fact existed. ${ }^{23}$ Another court stated that the "state is not necessarily the unrestrained master of what it creates and fosters." 24 In addition, several courts specifically found that when a school gave students an opportunity to speak publicly on issues that concerned them, even though the speech occurred on school grounds, for school credit, and imvolved the use of school funds and facilities, the school had created a forum for student expression. ${ }^{25}$

Courts have thus recognized that an official school newspaper is a forun for student expression entitled to first amendment protection, as long as the newspaper is something "more than a mere activity time and

19. Id. at 670 .

20. 454 U.S. 263 (1981).

21. See, e.g., Gambino v. Fairfax County School Bd., 429 F. Supp. 731, 736 (E.D. Va.) (recognizing secondary-school publication as public forum and stating that material could not be suppressed because it was objectionable to sclsool board or its constituents), aff'd per curiam, 564 F.2d 157 (4th Cir. 1977); Trujillo v. Love, 322 F. Supp. 1266, 1270 (D. Colo. 1971) (recognizing college newspaper as forum for student expression and invalidating requirement that student staff obtain faculty approval of any "controversial" material); Zucker v. Panitz, 299 F. Supp. 102, 104-05 (1969) (recognizing ligh-school newspaper as forum for dissemmation of ideas and lholding that students were entitled to publish advertisements paid for by students opposed to Vietnam War).

22. See, e.g., Zucker, 299 F. Supp. at 105 ("Defendants have [argned] that the [student newspaper] is not a newspaper in the usual sense, but is part of the curriculum and an educational device. ... We have found, from review of its contents, that within the context of the school and educational environment, it is a forum for the dissemination of ideas.").

23. Trujillo, 322 F. Supp. at 1268.

24. Antonelli v. Hammond, 308 F. Supp. 1329, 1337 (D. Mass. 1970).

25. See Bazaar v. Fortune, 476 F.2d 570, 574, aff'd as modified en banc per curiam, 489 F.2d 225 (5th Cir. 1973), cert. denied, 416 U.S. 995 (1974); Reineke v. Cobb County School Dist., 484 F. Supp. 1252, 1257 (N.D. Ga. 1980); Gambino, 429 F. Supp. at 734; Bayer v. Kinzler, 383 F. Supp. 1164 (E.D.N.Y. 1974), aff'd without op., 515 F.2d 504 (2d Cir. 1975); Lee v. Board of Regents, 306 F. Supp. 1097, 1100-01 (W.D. Wis. 1969), aff'd, 441 F.2d 1257 (7th Cir. 1971); Zucker v. Panitz, 299 F. Supp. 102 (S.D.N.Y. 1969); see also Stanton v. Brunswick School Dep't, 577 F. Supp. 1560, 1572 (D. Me. 1984) (finding substantial likelihood that yearbook used as vehicle for expression and transmission of personally held views constituted public forum and could not be subjected to government-sponsored censorship by vague, subjective, or nondiscrete standards). 
place sheet."26 Using this rationale, courts have upheld the rights of student journalists to publish a four-letter reference to a university president; ${ }^{27}$ a photograph of a burning American flag; ${ }^{28}$ an editorial calling for continued racial segregation of a university; ${ }^{29}$ advertisenents concerning race relations, unionization, and the Vietnam War; ${ }^{30}$ criticisn 1 a Governor and a state legislature; ${ }^{31}$ articles by nonstudents containing alleged obscenity; ${ }^{32}$ and "derogatory, profane, and blaspheinous" attacks on the Catholic Church. ${ }^{33}$ Moreover, courts in the post-Tinker era have held that broad categories of speech were protected and could not be censored from student publications. These categories included features on preinarital sex and the problems of teenage sexuality, along with such controversial topics as birth control and abortion. ${ }^{34}$ Also held protected were articles about drug abuse, including advocacy of the reform of drug laws; ${ }^{35}$ criticisms of school policies or personnel; ${ }^{36}$ unsigned articles; ${ }^{37}$ Inaterials offensive to good taste ${ }^{38}$ or presenting a negative innage of the school; ${ }^{39}$ and articles on such non-school-related topics as the draft or the war in Vietnam. ${ }^{40}$

These decisions were the direct progeny of Tinker. After almost twenty years, Tinker remamed the dispositive statement on student free speech rights. In Tinker, the Supreme Court stated that students "are 'persons' under our Constitution . . . possessed of fundamental rights which the State inust respect." ${ }^{\prime 1}$ Tinker held that absent a showing of

26. Zucker, 299 F. Supp. at 103.

27. Thonen v. Jenkins, 491 F.2d 722 (4th Cir. 1973) (per curiam).

28. Korn v. Elkins, 317 F. Supp. 138 (D. Md. 1970).

29. Joyner v. Whiting, 477 F.2d 456 (4th Cir. 1973).

30. Lee v. Board of Regents, 441 F.2d 1257 (7th Cir. 1971).

31. Dickey v. Alabama State Bd. of Educ., 273 F. Supp. 613 (M.D. Ala. 1967), vacated as moot sub nom. Troy State Univ. v. Dickey, 402 F.2d 515 (5th Cir. 1968).

32. Antonelli v. Hammond, 308 F. Supp. 1329 (D. Mass. 1970). (1973).

33. Panarella v. Birenbaum, 32 N.Y.2d 108, 112, 296 N.E.2d 238, 239, 343 N.Y.S.2d 333, 335

34. Shanley v. Northeast Indep. School Dist., 462 F.2d 960, 972 (5th Cir. 1972); Gambino v. Fairfax County School Bd., 429 F. Supp. 731, 733 (E.D. Va.), aff'd per curiam, 564 F.2d 157 (4th Cir. 1977); Bayer v. Kinzler, 383 F. Supp. 1164, 1165 (E.D.N.Y. 1974), aff'd without op., 515 F.2d 504 (2d Cir. 1975).

35. Shanley, 462 F.2d at 972.

36. Hatter v. Los Angeles City High School Dist., 310 F. Supp. 1309, 1310 (C.D. Cal. 1970), rev'd, 452 F.2d 673 (9th Cir. 1971); Scoville v. Board of Educ., 286 F. Supp. 988, 989 (N.D. III. 1968), rev'd, 425 F.2d 10 (7th Cir.), cert. denied, 400 U.S. 826 (1970).

37. Jacobs v. Board of School Comm'rs, 349 F. Supp. 605 (S.D. Ind. 1972), aff'd, 490 F.2d 601 (7th Cir. 1973), vacated as moot per curiam, 420 U.S. 128 (1975).

38. Leibner v. Sharbaugh, 429 F. Supp. 744 (E.D. Va. 1977); Shanley, 462 F.2d at 960.

39. Shanley, 462 F.2d at 960 ; Scoville, 286 F. Supp. at 988.

40. Riseman v. School Comm., 439 F.2d 148 (1st Cir. 1971) (per curiam); Zucker v. Panitz, 299

F. Supp. 102 (S.D.N.Y. 1969).

41. Tinker v, Des Moines Indep. Community School Dist., 393 U.S. 503, 511 (1969). 
"material and substantial interference with school work or discipline" schools could not restrain the first amendment rights of their students. ${ }^{42}$ That holding flowed directly from the Supreme Court's decision in West Virginia State Board of Education v. Barnette. ${ }^{43}$ There, the Court stated that "educating the young for citizenship is reason for scrupulous protection of Constitutional freedoms of the individual, if we are not to strangle the free mind at its source and teach youth to discount important principles of our governinent as mere platitudes."44

The Supreine Court decided ouly one high-school free speech case between Tinker and Kuhlmeier. In Bethel School District No. 403 v. Fraser, ${ }^{45}$ a seven-member inajority of the Court upheld a public school district's suspension of a student who used sexually suggestive puns in a speech at a school-sponsored assenbly. In a convoluted opinion written by Chief Justice Burger and delivered on the day of his retirement, the Court clainied to follow the Tinker standard by "tak[ing] into account consideration of the sensibilities of others" in upholding the suspension. ${ }^{46}$ In view of other opinions dealing with student free expression, ${ }^{47} \mathrm{Fraser}$ was an anoinaly. Kuhlmeier arose against this background and following this long history of judicial protection of the student press.

\section{KUHLMEIER-FACTS AND JUDICIAL HISTORY}

\section{A. Facts.}

Spectrum is the student newspaper at the Hazelwood East High School in St. Louis County, Missouri. ${ }^{48}$ During the spring semester of 1983, Kathy Kuhlmeier, Lee Ann Tippett, and Leshe Smart were inembers of Spectrum's staff and were enrolled in Hazelwood's Journalism II

\footnotetext{
42. Id.

43. 319 U.S. 624 (1943).

44. Id. at 637.

45. 478 U.S. 675 (1986).

46. Id. at 681 .

47. See supra note 21.

48. Kuhlmeier v. Hazelwood School Dist., 607 F. Supp. 1450, 1450 (E.D. Mo. 1985), rev'd, 795 F.2d 1368 (8th Cir. 1986), rev'd, 108 S. Ct. 562 (1988). The school provided approximately threefourths of the funds required to publish Spectrum, and the remaining fourth was raised through sales of the paper at 25ゅ per copy. Id. at 1452. Hazelwood East High School is a public school in St. Louis County, Missouri, run by the Hazelwood School District, with responsibility vested in a Board of Education. Id. at 1451. That Board governs the school's administrators, teachers, and approximately 1800 students. Id.

During the spring semester of 1983, Hazelwood East's High School principal and instructional leader was Robert E. Reynolds. Id. Spectrum was advised, prior to April 29, 1983, by Robert Stergos. Id. at 1452. After May 1, 1983, another teacher, Howard Emerson, assumed responsibility as faculty advisor until the end of the 1982-1983 academic year. See infra note 49.
} 
class. ${ }^{49}$ The primary activity of that class was to produce Spectrum. ${ }^{50}$ The Journalism II students were supposed to apply skills that they had acquired in previous classes and also learn to manage "leadership responsibilities." 51

While primary responsibility for the newspaper's content rested with the Journalism II students, other students could also submit articles or letters to the editor for publication. ${ }^{52}$ Three years before the incident in question, Spectrum had run an editorial entitled "The Right to Write." This editorial stated:

Because Spectrum is a member of the press and especially because Spectrum is the sole press of the student body, Spectrum has a responsibility to that student body to be fair and unbiased in reporting, to point out injustice and, thereby, guard student freedoms, and to uphold the high level of journalistic excellence. This may, at times, cause Spectrum to be unpopular with some. Spectrum is not printed to be popular. Spectrum is printed to inform, entertain, guide and serve the student body-no inore and, hopefully, no less. ${ }^{53}$

In furtherance of this pohicy, the students involved in publishing Spectrum at the beginning of the 1982-1983 school year published the following statement: "All non-by-lined editorials appearing in this newspaper reflect the opimions of the Spectrum staff, which are not necessarily shared by the admirnistrators or faculty of Hazelwood East." 54 The statement of policy also declared that "[o]uly speech that 'materially and substantially interferes with the requirements of appropriate discipline' can be found unacceptable and therefore prohibited." 55

The school board had also formulated several policies governing student publications. Board Policy 348.5(a) stated, "[s]tudents are entitled to express in writing their personal opinions." 56 Board Pohicy 348.51 fur-

49. These facts are drawn largely from the findings in Kuhlmeier, $607 \mathrm{~F}$. Supp. at 1450. The autliors were involved in the litigation as it evolved, and inany of the facts also are drawn from personal knowledge.

50. Id.

51. Id. at 1452 .

52. Id. at 1453 .

53. Id. at 1455 .

54. Id.

55. Id. The "Stateınent of Policy" quoted Tinker v. Des Moines Indep. Coinmunity School District, 393 U.S. 503, 509 (1969) (quoting in turn Burnside v. Byars, 363 F.2d 744, 749 (5th Cir. 1966)). According to Mr. Stergos, Spectrum published this "Statement of Policy" at the beginning of each academic year; however, the court received no documentary evidence on this point. Kullmeier, 607 F. Supp. at 1455. Consistent with this policy statement, Spectrum, in the years prior to the Kuhlmeier litigation, covered topics that included teenage dating, the effect of television on children, students' use of drugs and alcohol, race relations, teenage marriage, the death penalty, the St. Louis schools desegregation case, runaways, tecnage pregnancy, religious cults, the draft, school busing, and students' fourtl amendinent rights. Id. at 1453.

56. Kuhlmeier, 607 F. Supp. at 1455. 
ther provided that "[s]chool sponsored student publications will not restrict free expression or diverse viewpoints witlin the rules of responsible journalism." 57

For tlieir May 13, 1983, issue Spectrum's staff, witli tlie approval and aid of botlı its advisors, planned a six-page edition, ${ }^{58}$ including a two-page spread dealing witl articles of sensitivity and topicality to teenagers. ${ }^{59}$ The topics of the articles were (1) a primarily statistical look at teenage pregnancy, witlı a discussion of related topics including birth control and abortion; (2) a discussion of the then-controversial "squeal law" that would require federally funded clinics to notify parents when teenagers sought birtli control; (3) an account of three Hazelwood East students wlio became pregnant, with their names changed to protect tlieir identities; (4) an article on the seventy-five-percent failure rate of teenage marriages; (5) an article discussing teenage rumaways and available sources of lielp for them; and (6) an article discussing juvenile delinquency and the procedures available to deal witl delinquency probleins. ${ }^{60}$

Hazelwood principal Robert Reynolds required that Spectrum's faculty advisor submit eacli issue of the paper to him for approval prior to publication.61 The advisor tlius left the Spectrum galley proofs for Mr. Reynolds on May 10.62 On May 11, Mr. Reynolds reviewed the proofs during a teleplione conversation and directed the advisor to delete the two-page spread from the May 13 issue. ${ }^{63}$ Spectrum staff meinbers learned of the deletion only after viewing final copies of the paper delivered to the scliool for distribution on the morning of May 13.64 Upon protesting to the principal, the students learned that the deleted articles were "too sensitive" for "our immature audience of readers." 65 Mr. Reynolds's concerns focused on the article that provided personal accounts of three pregnant Hazelwood East students; he clamied that there were only eiglit to ten students at Hazelwood East wlio were pregnant tliat year, and thus the students discussed in the paper miglit be identifiable. ${ }^{66}$
57. Id.
58. See id. at 1459.
59. Id. at $1457-58$.
60. Id. at 1457 .
61. See id. at 1453-54.
62. Id.
63. Id. at $1458-59$.
64. Id.
65. Id.
66. Id. at 1460 . 


\section{B. Judicial History.}

In response to Mr. Reynolds's actions, Kuhlmeier, Tippett, and Smart filed suit in the United States District Court for the Eastern District of Missouri, seeking declaratory rehef, daunages, and injunctive relief ${ }^{67}$ for a violation of their constitutional rights. ${ }^{68}$ The district court ruled in favor of the school district, noting that while the Tinker decision granted students first aniendnient rights that did not stop at the schoolhouse gate, their rights were not "coextensive with those of adults" 69 and "[i]n the high school setting, school officials and teachers nuust be accorded a wide latitude over decisions affecting the inanner in which they educate students."70 The district court went on to distinguish between what it perceived as two lines of cases-one line conprising situations "where student speech or conduct occurred outside of official school prograins," and the other line "where the speech or conduct in question occurred within the context of school-sponsored progranıs."71 The court cited a total of ten cases 72 and noted that, in the second line of cases, when educators had attenipted to prohibit student speech in school-sponsored activities, the results had been mixed. ${ }^{73}$ Although the Supreine Court subsequently overruled one of these cases, ${ }^{74}$ at the time of the district court decision in Kuhlmeier, only two of the cited cases involved censorship of a school-sponsored newspaper. ${ }^{75}$ The district court, over-

67. Kuhlmeier, 578 F. Supp. at 1290. The court dismissed the claims for imjunctive relief on the ground that they had become moot when the plaintiffs graduated from Hazelwood High School. Kuhlmeier v. Hazelwood School Dist., 596 F. Supp. 1422, 1424 (E.D. Mo. 1984).

68. Kuhlmeier, 578 F. Supp. at 1289. The students sued under 42 U.S.C. $\$ \S 1983,1988$ (1982), which authorize lawsuits based on deprivations of constitutional rights. In this case the students alleged violations of their first and fourteenth amendment rights. See Kuhlmeier, 578 F. Supp. at 1289.

69. Kuhlmeier, 607 F. Supp. at 1462 (quoting Williams v. Spencer, 622 F.2d 1200, 1205 (4th Cir. 1980)).

70. Id. (quoting Nicholson v. Board of Educ., 682 F.2d 858, 863 (9th Cir. 1982)).

71. Id.

72. Fraser v. Bethel School Dist. INo. 403, 755 F.2d 1356 (9th Cir. 1985), rev'd, 478 U.S. 675 (1986); Nicholson, 682 F.2d at 858; Seyfried v. Walton, 668 F.2d 214 (3d Cir. 1981); Trachtman v. Anker, 563 F.2d 512 (2d Cir. 1977), cert. denied, 435 U.S. 925 (1978); Gaunbino v. Fairfax County School Bd., 564 F.2d 157 (4th Cir. 1977); Stanton v. Brunswick School Dep't, 577 F. Supp. 1560 (D. Me. 1984); Reineke v. Cobb County School Dist., 484 F. Supp. 1252 (N.D. Ga. 1980); Frasca v. Andrews, 463 F. Supp. 1043 (E.D.N.Y. 1979); Bayer v. Kinzler, 383 F. Supp. 1164 (E.D.N.Y. 1974), aff'd without op., 515 F.2d 504 (2d Cir. 1975); Zucker v. Parnitz, 299 F. Supp. 102 (S.D.N.Y. 1969).

73. Kuhlmeier, 607 F. Supp. at 1463.

74. Bethel School Dist. No. 403 v. Fraser, 478 U.S. 675,676 (1986).

75. Nicholson, 682 F.2d at 858; Frasca, 463 F. Supp. at 1043. Two other cases are distinguishable. In Seyfried, the students' first ainendment rights were not violated because the cancelled theatrical production was selected by faculty, not students. 668 F.2d at 217 n.2. In Trachtman, the school prohibited a sexual survey seeking information, not the distribution of information already obtained. 563 F.2d at 514-15. 
looking the fact that even in the so-called "second line" of cases, the students had usually prevailed, found this second line appticable. The court relied primarily on the decision of the Third Circuit in Seyfried $v$. Walton, ${ }^{76}$ which involved a high-school superintendent's decision to cancel a production of the musical Pippin, and found that "Spectrum was an integral part of Hazelwood East's curriculum, as opposed to a public forum for free expression by students." 77

The students appealed to the Urited States Court of Appeals for the Eighth Circuit. ${ }^{78}$ While the court of appeals for the most part accepted the district court's factual findings, it disagreed with the lower court's conclusion that Spectrum was not a public forum. The Eighth Circuit stated that "although Spectrum was produced by the Journalism II class, it was a 'student publication' in every sense."79 The court found substantial evidence that the students made the primary decisions about the paper's content, noting that even the paper's past advisor testified that it was the students' paper first and foreinost, that the students inade most of the content decisions, and that he reserved his input for questions of law or ethics. ${ }^{80}$ Also influencing the court was the breadth of subject matter covered by the newspaper, the sale of over 4500 copies in the 1982-1983 school year, and the policy statement published on September $14,1982.81$

Having determined that Spectrum was a forum for public expression, the Eighth Circuit rejected the district court's formulation that school officials must demonstrate only a "reasonable basis" for the actions they take ${ }^{82}$ and adopted the Tinker standard that any ban must be "necessary to avoid material and substantial interference with school work or discipline . . . or the rights of others." 83 Under that standard, the Eighth Circuit analyzed the principal's justification for censorshiphis concern that the teenage pregnancy story threatened a violation of the students' privacy. ${ }^{84}$ The court held that the school district's reasons did not justify this censorship. ${ }^{85}$ As the Eighth Circuit read the Supreme Court's statement in Tinker that suppression of expression would be jus-
76. 668 F.2d at 214 .
77. Kuhlmeier, 607 F. Supp. at 1465.
78. Kuhlmeier, 795 F.2d at 1368.
79. Id. at 1372 .
80. Id.
81. Id.
82. Kuhlmeier, 607 F. Supp. at 1466.
83. Kuhlmeier, 595 F.2d at 1374 (quoting Tinker v. Des Moines Indep. Community School Dist., 393 U.S. 503, 511 (1969)).
84. Id. at $1375-76$.
85. Id. at 1376. 
tified to protect invasions of rights, schools had power to suppress only speech that invaded rights defined under existing tort law standards. ${ }^{86}$ The court ruled that, because the girls involved had given their consent to be quoted in the articles and because the articles did not identify the fathers of the babies or expose any details about the lives of the girls' parents, no invasion of privacy had occurred. ${ }^{87}$ Having made these rulings, the Eighth Circuit remanded the case to the district court for a determination of damages. 88

Following the decision of the Eighth Circuit, the Hazelwood School District petitioned the Supreme Court for a writ of certiorari. The Court granted certiorari ${ }^{89}$ and scheduled argument.

\section{KUHLMEIER-THE SUPREME COURT DeCision}

The Supreme Court heard argument in Hazelwood School District $v$. Kuhlmeier on October 13, 1987, and rendered its decision three months later. ${ }^{90}$ By a vote of five to three, ${ }^{91}$ the Court overruled the Eighth Circuit. Although the Court started with the proposition from Tinker that students do not "shed their constitutional rights to freedom of speech or expression at the schoolhouse gate,"92 it rapidly added that "the First Amendment rights of students in public schools 'are not automatically coextensive with the rights of adults in other settings." "93

The Court then analyzed whether Spectrum was a forum for public expression; it agreed with the district court that no forum existed because the school had continued to exert control over the paper. ${ }^{94}$ Having determined that Spectrum was not in fact a public forum, the Court went on to question "whether the First Amendment requires a school affirmatively to promote particular student speech."95 In framing the question this way, the Court implicitly disregarded Spectrum's statement of policy, its disclaimer that the paper's views did not represent those of the school district, and the fact that Spectrum raised a significant portion of

86. Id. at 1375 (citing Note, Administrative Regulation of the High School Press, $83 \mathrm{MicH}$. L. REV. 625, 640 (1984)).

87. Id. at 1376 .

88. Id. at 1377.

89. 107 S. Ct. 926 (1987).

90. Kuhlmeier, $108 \mathrm{~S}$. Ct. at 562.

91. Justice White delivered the opinion of the Court, joined by Chief Justice Rehnquist and Justices Stevens, O'Connor, and Scalia. Justice Brennan filed a dissent, joined by Justices Marshall and Blackmun. See id.

92. Id. at 567 (quoting Tinker v. Des Moines Indep. Commumity School Dist., 393 U.S. 503, 506 (1969)).

93. Id. (quoting Bethel School Dist. No. 403 v. Fraser, 478 U.S. 675, 682 (1986)).

94. Id. at 567-68.

95. Id. at 569. 
its funding through sales. Instead, the Court focused on the school's provision of the funds not raised through sales and on the newspaper's production by students in a for-credit situation, considering these facts as evidence that the newspaper bore "the imprimatur of the school."96

The Court found this issue relevant not only to Spectrum, but to all "school-sponsored publications, theatrical productions, and other expressive activities that students, parents, and members of the public inight reasonably perceive to bear the imprimatur of the school."97 Thus, the Court intended the Kuhlmeier decision to apply to all activities that might "fairly be characterized as part of the school curriculum, whether or not they occur in a traditional classrooin setting, so long as they are supervised by faculty inembers and designed to impart particular knowledge or skills to student participants and audiences."98 The Court also stated that it considered a public high school the "pubhisher" of a school newspaper and the "producer" of a school play and that, as such, the school had the right to disassociate itself from speech that is "ungrammatical, poorly written, inadequately researched, biased or prejudiced, vulgar or profane, or unsuitable for immature audiences."99

In Kuhlmeier, the Court took an activist approach, deciding issues not necessary to determine the case at bar. Until its argument before the Supreme Court, the school district had raised only an invasion of privacy issue. ${ }^{100}$ Ignoring this limitation, the Court structured an extremely broad standard for permissible censorship, stating that "a school must be able to take into account the emotional maturity of the imtended audience in determining whether to disseminate student speech on potentially sensitive topics, which imight range from the existence of Santa Claus in an elementary school setting to the particulars of teenage sexual activity in a high-school setting."101 The Court went so far as to say that school officials could censor student expression that "might reasonably be perceived to advocate ... conduct otherwise inconsistent with 'the shared values of a civilized social order." "102 To assist school administrators in the performance of this guardianship, the Court stated that administrators' actions need only be "reasonably related to legitimate pedagogical concerns." 103

\section{Id.}

97. $I d$.

98. Id. at $\mathbf{5 7 0 .}$

99. $I d$.

100. See Appellees' Brief and Argument at 13-14, Kuhlmeier, 795 F.2d at 1368 (No. 85-1614).

101. Kuhlmeier, $108 \mathrm{~S}$. Ct. at 570 (emphasis added).

102. Id. (quoting Bethel School Dist. No. 403 v. Fraser, 478 U.S. 675, 683 (1986)).

103. Id. at $57 i$. 
The Supreme Court did not grant schools universal authority over publications, however. It imphitily left open the possibility that if facts indicated that a school had, by policy or practice, created a sclool-sponsored publication that was a forum, the Tinker standard would still apply. ${ }^{104}$ It expressly reserved the question of scliool authority over publications that are not school-sponsored activities, ${ }^{105}$ as well as the question of administrative autlority at the university or college level to censor "school-sponsored expressive activities."106

In dissent, Justice Brennan charged that the majority had essentially upset the balance of-if not implicitly overruled-Tinker. ${ }^{107} \mathrm{He}$ reminded the Court that it had once stated that the "mere desire to avoid the discomfort and unpleasantness that always accompany an unpopular viewpoint" did not justify official suppression of student speecli im the high schools. ${ }^{108}$ To Justice Brennan, the Court's distmction between school-sponsored publications and speech occurring in a nonsponsored or independent fashion (lifted largely from the district court's decision) was an artificial one that lacked prior support. 109

Justice Brennan noted that the Court offered "an obscure tangle of three excuses" to justify its decision: "the public educator's prerogative to control curriculum; the pedagogical niterest in1 shielding the higl1 school audience fron objectionable viewpoints and sensitive topics; and the school's need to disassociate itself from student expression."110 The dissent furiously criticized the second justification-tlre idea that a school is responsible for shieldnig impressionable high-school audiences fronı unsuitable material - by discussing a line of decisions that, in Justice Brennan's view, invahidated the presumed right of the school to act as a member of the "tliought pohice."11 $\mathrm{He}$ also pointed out that the

104. See Kuhlmeier, $108 \mathrm{~S}$. Ct. at 567-68. One court has already misinterpreted Kuhlmeier in this regard. In Planned Parenthood of Southern Nev., Inc. v. Clark County School Dist., No. 84765 RDF, slip op. (D. Nev. Apr. 5, 1988), appeal pending, the district court ignored the "pohicy and practice" language of Kuhlmeier and said that school-sponsored publications are now incapable of being public forums. Id., slip op. at 7 ("high school newspapers and other student publications are not public fora").

105. $108 \mathrm{~S}$. Ct. at 571 n.6.

106. Id. at 571 n.7.

107. Id. at 575 (Brennan, J., dissenting).

108. Kuhlmeier, $108 \mathrm{~S}$. Ct. at 575 (quoting Tinker v. Des Moines Indep. Commurity School Dist., 393 U.S. 503, 509 (1969)).

109. Id.

110. Id. at 576 .

111. Id. at 577 (citing Epperson v. Arkansas, 393 U.S. 97 (1968); Keyishian v. Board of Regents, 385 U.S. 589 (1967); Meyer v. Nebraska, 262 U.S. 390 (1923)). Justice Brennan noted that of the "thrce excuses," the first concern is fully addressed by the Tinker decision, the second concern is illegitimate, and the third is readily addressed by less oppressive ineans. Note, however, that even Justice Brennan thought that a basis exists for an educator's right, under Tinker, to "censor" poor 
Court's third concern, the school's right to disassociate itself from speech, could easily be handled by requiring the newspaper to publish a disclaimer or by issuing a response to the newspaper, both significantly less intrusive than the censorship powers granted by the Court. ${ }^{112}$

Justice Brennan's dissent concluded that there is no way to reconcile the Kuhlmeier decision with the Tinker decision, and that Kuhlmeier at least partially overrules the case from which it claims logically to descend. ${ }^{113}$ We now consider the legacy of the Kuhlmeier decision.

\section{THE Legacy OF KUHLMEIER}

\section{A. Redefining Public Forums in High Schools.}

As parts II and III have noted, three different courts took exceedingly different views on whether Spectrum qualified as a forum for public expression. We beheve that both the district court and the Supreme Court decided this question incorrectly. Both courts erred as to schoolsponsored student newspapers in general and Spectrum in particular. In fact, in ruling that Spectrum was a public forum, the Eighth Circuit rehed on the same factual findings made by the district court in its ruling that Spectrum was not a public forum.114

The record contained sufficient evidence to support the ruling that a forum existed and that Spectrum, like other student publications, was "conceived, established, and operated as a conduit for student expression on a wide variety of topics." 115 Even the district court conceded that "students not enrolled in Journalism II could submit material for publication" and that a column entitled "Letters to the Editor" was open to students who were not enrolled in Journahism II and did not receive credit for their submissions. ${ }^{116}$ Also left uncliallenged were Spectrum's consistent coverage of issues of interest to the entire Hazelwood Scliool District coinmumity and its ability to raise approximately one-fourtli of its income through sales. ${ }^{117}$

Even the Hazelwood School District's own policies, which allowed students freedom of written expression and prohibited scliool censor-

grammar, writing, or research because such items unight materially disrupt a newspaper's curricular purpose. Id. at 576 .

112. Id. at 579 (citing Keyishian, 385 U.S. at 602).

113. Id. at 580 .

114. Kuhlmeier, 795 F.2d at 1372.

115. Gambino v. Fairfax County School Bd., 429 F. Supp. 731, 735 (E.D. Va.), aff'd per curiam, 564 F.2d 157 (4th Cir. 1977); see also Student Press LAw Center, LAw of the Student Press 14-15 (1985) (discussing forum theory in Gambino).

116. Kuhlmeier, 607 F. Supp. at 1453.

117. Id. at $1452-53$. 
ship, ${ }^{118}$ established that the school district intended Spectrum as a forum for student expression. These pohicies reaffirmed the experience of students who worked on the staff of the student newspaper at Hazelwood East: Spectrum was by intention and in fact a student newspaper for the presentation of student news, views, and opinions. ${ }^{119}$

These facts should have been determinative. Few student newspapers, official or unofficial, distributed for free or sold, provide the stinulation for public debate present in Spectrum's articles. Of the three courts that examined Spectrum's status, not even the Eighth Circuit, the only court to rule in favor of the students, focused on the idea that the determination whether or not a publication is a forum for public expression should be based upon how information is received and used as well as how it is produced. ${ }^{120}$

The Supreme Court, in its rush to find an expansive rationale for handing schools more control, neglected to properly analyze the forum issue. Rather than discussing the fact that cities and states create parks, public squares, and courthouse steps, rarely expecting them to be used as forums for public expression, the Supreine Court fell back on its stateinent in Perry Education Association v. Perry Local Educators' Association ${ }^{121}$ that "school facilities may be deemed to be public forums only if school authorities have 'by pohcy or by practice' opened those facilities 'for indiscriminate use by the general public.' "122

118. See supra notes 56-57 and accompanying text.

119. Spectrum's situation at Hazelwood East compares to that of other student publications recognized, before Kuhlmeier, as protected by the first amendment. In Zucker v. Panitz, 299 F. Supp. 102 (S.D.N.Y. 1969), the court prevented censorship of a student newspaper that school officials described as a curricular device "intended to inure primarily to the benefit of those who compile, edit and publish it." Id. at 103. The court indicated that such a claim was without merit and noted that the newspaper was sold to the student body, included letters to the editor, and ran stories on controversial topics: "It is clear that the newspaper is more than a mere activity time and place sheet." Id.; see also Bazaar v. Fortune, 476 F.2d 570, 572, 574-75 (5th Cir.) (literary magazine produced with advice of college English department and connected to course for credit found to be public forum), aff'd as modified en banc per curiam, 489 F.2d 225 (5th Cir. 1973), cert. denied, 416 U.S. 995 (1974); Gambino, 429 F. Supp. at 735 (high-school newspaper with some staff members enrolled in journalism class and receiving academic credit for work on newspaper found to be a public forum); Stanton v. Brunswick School Dep't, 577 F. Supp. 1560, 1570-71 (D. Me. 1984) (highschool yearbook that allowed students to include short quote next to photograph was de facto public forum for purposes of granting preliminary injunction).

In a factual situation difficult to distinguish from Kuhlmeier, the court in Reineke v. Cobb County School Dist., 484 F. Supp. 1252 (N.D. Ga. 1980), held that a preliminary injunction against censorship was appropriate, because a substantial likelihood existed that the trial court would hold the official high-school newspaper protected from censorship. In Reineke, the student editors and staff received academic credit for enrollment in a journalism class whose teacher was the newspaper's advisor as well. See id. at 1255.

120. See Kuhlmeier, 795 F.2d at 1373-74.

121. 460 U.S. 37 (1983).

122. Kuhlmeier, 108 S. Ct. at 568 (quoting Perry, 460 U.S. at 47). 
In Perry, the Supreme Court established three categories of forums under the public forum doctrine: (1) the quimtessential public forum, (2) the limited public forum, and (3) the nonpublic forum. ${ }^{123}$ In this scheme, a school-sponsored student newspaper like Spectrum is a limited public forum. A student newspaper is concededly not a quintessential public forum like a street or a park. But, as the Supreme Court noted in Perry, a "public forum" may be created for a limited purpose such as use by certain groups. ${ }^{124}$ The school district made Spectrum a forum open for general use by a limited group-students. ${ }^{125}$ In stark contrast to Perry, in which the school district had a written contract limiting the distribution of inaterials through faculty mailboxes, the Hazelwood School District's policies encouraged written student expression. ${ }^{126}$ The facts, as found by the district court and accepted by both the Eiglith Circuit and the Supreme Court, showed that the school established the student newspaper for use by a limited public of student staff inembers as a place for their expressive activity.

By misapplying Perry to what was in fact a public forum, the Supreme Court provided schools with an easy inechanisin for determinimg whether or not their student newspaper is a forum for public expression. ${ }^{127}$ Most schools will interpret the decision as giving them the authority to control a student newspaper unless they designate it a public forum. However, schools that censor will not do their students or their educational goals a service.

\section{B. The Social Impact of the Kuhlmeier Decision.}

As noted above, 128 the Supreme Court has drawn a box around school-sponsored publications, stating that they are not forums for public expression uuless policy or practice gives clear evidence of such a designation. Many schools will censor as a result of this decision. We now examine the plight of students at those schools.

123. Perry, 460 U.S. at $45-46$.

124. Id. at 46 n.7.

125. See Widmar v. Vincent, 454 U.S. $263,267-68$ n.5 (1981).

126. See supra notes 56-57 and accompanying text.

127. The public forum doctrine is not the only method for defining and protecting student free press rights. However, a Supreme Court that approved so restrictive a stance was not likely to search for other rationales to justify students' free speech. In protecting student journalists, many lower courts have relied on a pure free press analysis similar to that enunciated by the Supreme Court in Miami Herald Pub. Co. v. Tornillo, 418 U.S. 241 (1974). See Stanley v. McGrath, 719 F.2d 279, 282 (8th Cir. 1983); Sinn v. Daily Nebraskan, 638 F. Supp. 143, 146-48 (D. Neb. 1986), aff'd, 829 F.2d 662 (8th Cir. 1987); Reineke v. Cobb County School Dist., 484 F. Supp. 1252, 1256-57 (N.D. Ga. 1980); Bayer v. Kinzler, 383 F. Supp. 1164, 1165-66 (E.D.N.Y. 1974), aff'd without op., 515 F.2d 504 (2d Cir. 1975).

128. See supra notes $94-99$ and accompanying text. 
For students who want to work on the staff of a school newspaper, the Kuhlmeier decision puts them to a Hobson's Choice between staying with the school-sponsored publication or working for (or founding) a non-official, "underground" publication. A student who stays with the official publication will continue, in many cases, to receive credit for her participation. That is a value not to be underestimated in the crowded life of a teenager; demands on a teenager's time force difficult decisions. Moreover, the serious student who wants to be a journalist, or merely wants to learn to write better, will recognize the clear advantage in having access to a journalism advisor, particularly if that advisor has formal experience or training in writing and journalism. For students such as these, the benefit of having a professional overseeing the development of their writing and reporting skills is imcalculable. In the wake of the Kuhlmeier decision, the student who maintains ties with the student publication in order to gain these advantages will merely have to sacrifice her editorial freedoin.

Conversely, a student can join an underground publication, if one exists, or otherwise seek to form one. The clear advantage of working on such a publication after the Kuhlmeier decision is its editorial freedom. The publication will not be part of the school's curriculum or funded by the school. Therefore, school control will be limited to the administrators' ability to intercept the publication before its dissemination to students on school grounds. As we discuss below, ${ }^{129}$ school adminnstrators will be limited even in their ability to do this. However, the student who chooses to go underground will have to sacrifice credit and educational input. Students' sole "educators" in an underground newspaper will be other students who are at most a year or two older. Students participating in such publications will trade educational benefits for the right to experience journalistic first amendment freedoms "at their apogee."130

In forcing student journahists to make this choice, the Supreine Court has sent a message not only to student journalists, but also to all public school students. It has told them in the past that the educational system exists to inculcate in toinorrow's leaders the "fundainental values necessary to the maintenance of a deinocratic political system."131 It has also stated that public education serves to prepare the youth of our nation to deal with "our increasingly complex society and ... the duties of citizenship in our dennocratic Republic." 132 The Court is now telling stu-

129. See infra notes 158-69 and accompanying text.

130. Kuhlmeier, 607 F. Supp. at 1463.

131. Ambach v. Norwick, 441 U.S. 68, 77 (1979).

132. Kuhlmeier, $108 \mathrm{~S}$. Ct. at 573 (Brennan, J., dissenting); see also Brown v. Board of Educ., 347 U.S. 483, 493 (1954) ("Today, education is perhaps the most important function of state and 
dents, however, that they must receive these values passively, without an opportumity to debate on a schoolwide basis the issues and concerns of the day. It blithely presumes that other equally efficient mechanisms, such as the local news media, will enable students in a public higli school to receive the information they need to make their own choices about such issues and concerns.

This presumption is naive. Small-town newspapers frequently shy away from discussing controversial issues relating to the children in their readership. Equally specious is the idea that, in a major metropohitan area, a newspaper will devote sufficient space to the umique concerns of the teenage population, which does not, after all, buy microwaves, sheets, expensive automobiles, or even many copies of the newspaper.

As a result, the major source of information for teenagers will be other teenagers, from whoin there is no guarantee that the information provided is correct. With a student newspaper, properly supervised by a member of a high-school faculty cognizant of student journalists' right to free speech, there was both discussion of sensitive issues and a general assurance of accuracy. The Supreme Court has disrnpted this balance, forcing a choice between discussion and accuracy. Moreover, the Court has sent a message to the students of America that constitutional guarantees do, indeed, largely stop at the schoolhouse gate. ${ }^{133}$ Students are taught that they must pay homage to the values of the Constitution even though they will have no enforceable constitutional rights until they receive their high-school diploma.

The likely effect of such a message is student cymicism. Students who might have eagerly awaited a chance to participate in our system as adults may instead pursue more parochial concerns. Students who might have considered careers in journalism will turn instead to otlier interests. These cannot be the messages that the Supreme Court intended to send the youth of America.

\section{The Legal Aftermath of the Kuhlmeier Decision.}

1. Demise of the Disruption Standard. Prior to the Kuhlmeier decision, the Supreme Court and the lower courts had lield that student

local governments .... It is required in the performance of our most basic public responsibilities .... It is the very foundation of good citizenship. . . . In these days, it is doubtful that any child may reasonably be expected to succeed in life if le is denied the opportunity of an education.").

133. Cf. Bethel School Dist. No. 403 v. Fraser, 478 U.S. 675, 685 (1986) (student does not liave a first amendinent riglit to utter lewd and indecent speecli at high-scliool asseinbly); New Jersey v. T.L.O., 469 U.S. 325, 341-42 (1985) (search of student by scliool official or teacher does not violate the student's fourtl amendment rights and is " 'justified at its inception' when there are reasonable grounds for suspecting that the search will turn up evidence that the student lias violated ... the law or the rules of the scliool."). 
expression could be censored only if it caused "substantial disruption."134 The Supreme Court in Kuhlmeier, however, has developed a new standard for school-sponsored publications; the standard no longer requires substantial disruption, but rather allows editorial control over student speech so long as the control is "reasonably related to legitimate pedagogical concerns." 135

In creating this new standard, the Supreme Court has, without sufficient justification, disemboweled the disruption standard for school-sponsored publications. From 1969 to 1988, in only one case were school officials able to convince a court that a material and substantial disruption of a high school would in fact have occurred had certain material been published in a school-sponsored student publication. ${ }^{136}$ In that case, the court held that an editorial reference in the student newspaper to "hot-headed, egotistical, 'pissed-off' jocks" could have resulted in a physical disruption. The court based its decision on the unsupported opinion of three school officials: the building principal who was the censor, the coach of the athletes referred to, and an Enghish teacher who was the newspaper's faculty advisor. ${ }^{137}$

Nor did the Supreme Court in Kuhlmeier need to alter the disruption standard. There was no evidence that the Spectrum articles would have disrupted classes. There was also no reasonable forecast of an unwarranted invasion of privacy as a resnlt of the stories. ${ }^{138}$ As the Eighth Circuit noted, Spectrum staffers obtained the consent of all those interviewed. ${ }^{139}$ Significantly, none of the interviewed students complained about the stories, which were subsequently published in their entirety in

134. Tinker v. Des Moines Indep. Community School Dist., 393 U.S. 503, 509 (1969); see also Shanley v. Northeast Indep. School Dist., 462 F.2d 960, 969 (5th Cir. 1972); Scoville v. Board of Educ., 425 F.2d 10, 13 (7th Cir.), cert. denied, 400 U.S. 826 (1970); Burnside v. Byars, 363 F.2d 744, 749 (5th Cir. 1966); Blackwell v. Issaquena County Bd. of Educ., 363 F.2d 749, 754 (5th Cir. 1966); Leibner v. Sharbaugh, 429 F. Supp. 744, 749 (E.D. Va. 1977); Vail v. Board of Educ., 354 F. Supp. 592, 598 (D.N.H. 1973), vacated and remanded, 502 F.2d 1159 (Ist Cir. 1973); Sullivan v. Houston Indep. School Dist., 307 F. Supp. 1328, 1340 (S.D. Tex. 1969).

135. Kuhlmeier, $108 \mathrm{~S}$. Ct. at 571.

136. Frasca v. Andrews, 463 F. Supp. 1043 (E.D.N.Y. 1979). In another case, Trachtman v. Anker, 563 F.2d 512 (2d Cir. 1977), cert. denied, 435 U.S. 925 (1978), the United States Court of Appeals for the Second Circuit held, over a persuasive dissent, that the distribution of a student survey on sexual practices met the Tinker standard for censorship. The case, lowever, did not involve material that a student newspaper was seeking to publish.

137. Frasca, 463 F. Supp. at 1051.

138. As the court of appeals noted, it is specious to define Tinker's "invasion of the rights of others" standard to allow censorship of material that is not materially and substantially dismptive or a tortious invasion of privacy. Kuhlmeier, 795 F.2d at 1376.

139. Id. A minor's consent is effective if he is capable of appreeiating the nature, extent, and probable consequences of the conduct to which he consents, even if parental consent is not obtained or expressly refused. RESTATEMENT (SECOND) OF TORTS § 892A (1982). Although the scliool district presented witnesses at trial who claimed they could identify the students interviewed for the 
a regional newspaper. ${ }^{140}$ The Hazelwood School District was motivated by discomfort about the discussion of teenage pregnancy and divorce, not by fear of disruption or concerns with invading privacy. A blanket prohibition of such controversial topics threatens "a value at the very core of the First Amendment."141

Kuhlmeier involved viewpoint suppression, not fear of substantial disruption. It was the "sexual norm" of the three pregnant students, as the school district described it, ${ }^{142}$ that provided the basis for the school's decision to censor. Thus, notwithstanding that in twenty years only one court had found a need to uphold the censorship of an official schoolsponsored publication under the higher substantial disruption standard ${ }^{143}$ and that the Kuhlmeier record contained no evidence of interference with education as a resnlt of the articles, the Suprene Court in Kuhlmeier needlessly changed the standard to allow for wide-ranging control of student speech by school administrators.

Were a concern that education was suffering under the Tinker standard well-founded, common sense wonld indicate that high schools not imposing prior restraints would be in chaos. In Fujishima v. Board of Education, ${ }^{144}$ the Seventh Circuit held unconstitutional a school regulation requiring prior approval and allowing restraint of student publications distributed on school grounds. Yet in the years smce Fujishima, there lias been no suggestion that high-sclool education in Illinois, Wisconsm, or Indiana has suffered because of the limitations on prior restraints. The Seventh Circuit considered sufficient the schools' autliority to subsequently punish students for activity that creates a inaterial disruption. ${ }^{145}$ Moreover, the court left school officials the option to seek injunctive relief when they anticipate that a situation warrants the extreine and immediate action of prior restraint. Yet no indication exists that even once im sixteen years has a scliool official in any of the three states sought prior restraint through an injunction.

In Kuhlmeier, the Supreme Court took an approach almost diainetrically opposed to the Seventh Circuit's approach in Fujishima. While

pregnancy story, it presented no evidence that any of the students portrayed in the story lacked capacity to understand the effect of their consent.

140. Too Hot for Hazelwood, St. Louis Globe Delnocrat, Dec. 9, 1985, Weekend Section, at 5.

141. Consolidated Edison Co. v. Public Serv. Comm'n, 447 U.S. 530, 548 n.9 (1980) (Stevens, J., concurring).

142. See Brief for Petitioners at 34-36, Kuhlmeier, $108 \mathrm{~S}$. Ct. at 562 (No. 86-836). Interestingly, petitioner's amicus, Pacific Legal Foundation, had no hesitation in noting the viewpoints suppressed. Brief Amicus Curiae of Pacific Legal Foundation in Support of Petitioners at 15-17, Kuhlmeier (No. 86-836).

143. See supra notes $136-37$ and accoinpanying text.

144. 460 F.2d 1355 (7th Cir. 1972).

145. See id. at 1359. 
the Kuhlmeier approach will prevent school-sponsored publications from interfering with the educational process, in light of past judicial decisions and experience, the Court is using an atom boinb to swat a fly.

\section{The Creation of a Two-Tiered Student Press-School-Sponsored} and Non-School-Sponsored Publications. Not every paper that schools miglit perceive as school-sponsored comes within the ambit of the Kuhlmeier decision. Those publications that in practice have been forums for student expression will be unaffected. In addition, it is unclear what level of support or institutional involvement Kuhlmeier requires before a publication comes "to bear the imprimatur of the school."146 As a legal matter, what does "school-sponsored" mean? Does an afterhours newspaper club produce a scliool-sponsored paper, simply because a teacher supervises it or because it receives some scliool funds that incidentally help to produce the newspaper?

Schools might attempt to avoid these questions suggested by the Kuhlmeier decision by designatimg all student publications nonforums. To do this, schools inight try to change currently independent newspapers, now labeled forums, or newspapers produced by clubs, into newspapers labeled nonforums and produced within a class for credit under the supervision of a faculty member. Although the Kuhlmeier decision greatly expands schools' powers, it is unclear whetler a school could successfully convert a newspaper from a forum imto an official, nonforum publication.

Attempting to cliange the status of a newspaper solely to gain control over its content is analogous to other actions that high-school principals and college presidents lave taken in the past to control the content of student publications indirectly. Courts have swiftly and umformly rejected schools' attempts to gain control over the content of a newspaper by withdrawing financial support, ${ }^{147}$ or by dismissing or suspending its editors. ${ }^{148}$ In light of these decisions, attempts to convert a publication from forum to nonforum for the stated or intended purpose of gaining editorial control over the publication would likewise be found unconstitutional.

146. Kuhlmeier, 108 S. Ct. at 569.

147. See, e.g., Joyner v. Whiting, 477 F.2d 456 (4th Cir. 1973); Reineke v. Cobb County School Dist., 484 F. Supp. 1252 (N.D. Ga. 1980); Antonelli v. Hammond, 308 F. Supp. 1329 (D. Mass. 1970).

148. See, e.g., Schiff v. Williams, 519 F.2d 257 (5th Cir.), cert. denied, 423 U.S. 834 (1975); Thonen v. Jenkins, 517 F.2d 3 (4th Cir. 1975); Trujillo v. Love, 322 F. Supp. 1266 (D. Colo. 1971); Dickey v. Alabama State Bd. of Educ., 273 F. Supp. 613 (M.D. Ala. 1967), vacated as moot sub nom. Troy State Univ. v. Dickey, 402 F.2d 515 (5th Cir. 1968). 
3. The Liability Factor. Even if school administrators convince courts to allow thein to bring student publications under school control, there is a good reason why public institutions would not want such control: those who dictate the content of a publication will have financial responsibility for any tortious material that appears in it. ${ }^{149}$ Absent such a control relationship, no financial responsibility for the content of student publications exists.

Furthermore, the Supreine Court has recognized, in a slightly different context, that officials who merely follow the dictates of the first amendment are not financially liable for the torts of others. In Farmers Educational \& Cooperative Union v. WDAY, Inc., ${ }^{150}$ the Court held that broadcasting stations hicensed by the Federal Communications Cominission are barred from removing defamatory statements contained in speeches by candidates for public office. If such censorship were permissible, the Court said, "a station so inclined could intentionally inhibit a candidate's legitimate presentation under the guise of lawful censorship of libelous matter." 151 Having recognized the legal inability to censor, however, the Court stated that a licensee who broadcast a candidate's defamatory stateinents would enjoy immunity fronı liability. Withholding immunity would allow the "unconscionable result" of permitting liability for the very conduct that the law demands. ${ }^{152}$ "Quite possibly, if a station were held responsible for the broadcast of libelous inaterial [of political candidates], all reinarks even faintly objectionable would be excluded out of an excess of caution." 153

At least two courts have applied this rationale to student newspapers at public institutions of higher education. In these cases, when the crucial control element was missing, that is, when a public school followed the established first amendinent constraints and did not control the content of the student newspaper, the sclool was immune from liability. ${ }^{154}$ Thus, an educational institution that refrains froin censorship protects itself from financial liability for torts that it slould be in no position, constitutionally or educationally, to prevent. Thus, after Kuhlmeier, to convert a student newspaper providing a forum for stu-

149. Three factors determine whether or not such a control or agency relationship exists: (1) consent, (2) benefit, and (3) right of control. See Restatement (SECOND) of AGENCY $§ 1$ (1958).

150. 360 U.S. 525 (1959).

151. Id. at 530 .

152. Id. at 531 .

153. Id. at 530.

154. Milliner v. Turner, 436 So. 2d 1300 (La. Ct. App.), cert. denied, 442 So. 2d 453 (La. 1983);

Mazart v. State, 109 Misc. 2d 1092, 441 N.Y.S.2d 600 (Ct. Cl. 1981). 
dent expression into a nonforum publication could be a serious financial mistake.

4. Questions Remaining After Kuhlmeier. Although Kuhlmeier appears to be a tsunami that has wiped out all that existed before, upon closer inspection, protections remain for student journalists' exercise of free speech. For example, the Supreme Court, in footnote 7 of Kuhlmeier, explicitly reserved the question whether a student publication at the college or university level has protection from the wide-ranging powers granted to secondary-school administrators in Kuhlmeier. ${ }^{15 s}$ Although many university administrators may attempt to use Kuhlmeier as a green light for censorship in higher education, the courts will likely use Kuhlmeier's footnote 7 to limit the case's impact to the high-school level. The courts' reasons will include the older age of college newspaper reporters, the concomitantly higher age of these newspapers' readers, the increased independence generally granted to students in higher education, and the acknowledgement that such students are, in fact, young adults with full legal rights in our system (save, in most states, the right to drink).

Likewise, Kuhlmeier is limited by its own terms to secondaryschool-sponsored publications that are not public forums for student expression. Therefore, the case should be read to exclude from administrative control any newspaper that is "underground" or independent. ${ }^{156}$

In the post-Kuhlmeier world, publications at institutions of higher education and independent (or forum) publications in secondary schools retain, for the time being, extensive first amendment protections. College and university publications still may not be censored, and the voices of independent secondary-school publications can only be restricted when schools afford due process. ${ }^{157}$

For these publications, the first amendment requires that speech re-

155. Kuhlmeier, $108 \mathrm{~S}$. Ct. at 571 n.7 ("We need not now decide whether the same degree of deference is appropriate with respect to school-sponsored expressive activities at the college and university level.").

156. Supporting the idea that underground newspapers are not included in the ambit of the Kuhlmeier decision is the Supreme Court's statement that the distinctions drawn in permitting curriculum control are fully consistent with the decision involving a university-level underground in Papish v. Board of Curators, 410 U.S. 667 (1973). Kuhlmeier, 108 S. Ct. at 570 n.3. Equally persuasive is the Court's suggestion that "[w]e need not now decide whether such [specific written] regulations are required before school officials may censor publications not sponsored by the school that students seek to distribute on school grounds." Id. at 571 n.6. Thus, the Supreme Court has presumptively left valid the decisions in Baughman v. Freienmuth, 478 F.2d 1345 (4th Cir. 1973); Shanley v. Northeast Indep. School Dist., 462 F.2d 960 (5th Cir. 1972); Eisner v. Stamford Bd. of Educ., 440 F.2d 803 (2d Cir. 1971); and other cases involving underground publications.

157. See Nitzberg v. Parks, 525 F.2d 378, 383 (4th Cir. 1975); Gambino v. Fairfax County School Bd., 429 F. Supp. 731, 736 (E.D. Va.), aff'd per curiam, 564 F.2d 157 (4th Cir. 1977). 
strictions be "narrowly drawn."158 For such regulations to escape a void-for-vagueness determination, they must be enumerated with "suffcient definiteness that ordinary people can understand what conduct is prohibited and in a manner that does not encourage arbitrary and discriminatory enforceinent." 159

Prior restraints, if they are to exist at all, ${ }^{160}$ must ineet certain minimal requirements. The regulations must offer criteria and specific exainples so that students will understand what expression is proscribed. ${ }^{161}$ They must detail the criteria by which an administrator might reasonably predict "substantial disruption."162 The regulations inust provide definitions of all key terms used, ${ }^{163}$ such as "defamatory." Students must be given an opportunity to know that such rules exist; the regulations unust be included in an official school publication or circulated to students in the same inanner as other official niaterial. ${ }^{164}$ These publication guidehines also inust specify who approves material ${ }^{165}$ and must give the students the right to a prompt hearing before the decisionmaker and the opportunity to argue in favor of distribution. ${ }^{166}$ Procedural due process also requires that publication guidelines limit the official's time to reach a decision to prevent distribution, ${ }^{167}$ provide for the contingency of an administrator failing to issue a decision within that time, ${ }^{168}$ and include an expeditious procedure for appealing that decision. ${ }^{169}$ These requirements

158. In re Primus, 436 U.S. 412, 438 (1978).

159. Kolender v. Lawson, 461 U.S. 352, 357 (1983). The Supreme Court's formulation allowing only censorship that is "reasonably related to legitimate pedagogical concerns," Kuhlmeier, $108 \mathrm{~S}$. Ct. at 571, would have been held void for vagueness if expounded by a school board as part of a regulation.

160. Fujishima v. Board of Educ., 460 F.2d 1355 (7th Cir. 1972), still prohibits prior review of independent publications withm the jurisdiction of the Seventh Circuit.

161. Nitzberg, 525 F.2d at 383; Baughman v. Freienmuth, 478 F.2d 1345, 1349 (4th Cir. 1973); Shanley v. Northeast Indep. School Dist., 462 F.2d 960, 976-77 (5th Cir. 1972).

162. Nitzberg, 525 F.2d at 383.

163. See Hall v. Board of School Comm'rs, 681 F.2d 965, 971 (5th Cir. Unit B 1982) (defining "distribution"); Nitzberg, 525 F.2d at 383 (defiming "libelous"); Shanley, 462 F.2d at 977 (defining "distribution").

164. See Nitzberg, 525 F.2d at 383 n. 4 ("We believe that a more effective notice would be attained through inclusion in official publications of the school or circulated to students in the same manner as other official materials ....").

165. Eisner v. Stamford Bd. of Educ., 440 F.2d 803, 811 (2d Cir. 1971).

166. Leibner v. Sharbaugh, 429 F. Supp. 744,749 (E.D. Va. 1977).

167. See Baughman v. Freienmuth, 478 F.2d 1345, 1348 (4th Cir. 1973); Shanley v. Northeast Indep. School Dist., 462 F.2d 960, $977-78$ (5th Cir. 1972); Eisner, 440 F.2d at 810; Leibner, 429 F. Supp. at 749.

168. See Baughman, 478 F.2d at 1348.

169. See Hall v. Board of School Comm'rs, 681 F.2d 965, 969 (5th Cir. Unit B 1982); Baughman, 478 F.2d at 1349; Shanley, 462 F.2d at 977-78; Quarterman v. Byrd, 453 F.2d 54, $59-60$ (4th Cir. 1971); Leibner, 429 F. Supp. at 749. 
survive Kuhlmeier and guarantee vitality for the independent student press at the high-school level.

Nevertheless, in the wake of Kuhlmeier the outlook for the student press is not all rosy. The decision has overruled a significant amount of precedent from the last twenty years. It would be liard to argue that decisions stating that high-school administrators lack the power to control the content of a school-sponsored newspaper prior to publication have the same vitality. ${ }^{170}$ Although these cases will no longer apply to publications found to be nonforums, other cases providing considerable protection for the student press, including those relating to non-schoolsponsored and forum publications, still retain their vitality. Thus, in Illinois, Indiana, and Wisconsin, Fujishima v. Board of Education ${ }^{171}$ continues to render facially unconstitutional, and thus unenforceable, public higl schools' prepublication administrative review of non-school-sponsored publications.

5. State-Law Approaches. Finally, even though Kuhlmeier has weakened much of the federal law of the last twenty years im the school newspaper field, a layer of state regulation and caselaw in many jurisdictions retains and expands protections of the student press, mcluding scliool-sponsored publications. For example, California and Massachusetts protect the rights of the student press by statute. ${ }^{172}$ This protection, which prevents school administrators from interfering witl the exercise

170. See Reineke v. Cobb County School Dist., 484 F. Supp. 1252 (N.D. Ga. 1980); Gambino v. Fairfax County School Bd., 429 F. Supp. 731, 736 (E.D. Va.), aff'd per curiam, 564 F.2d 157 (4th Cir. 1977); Bayer v. Kinzler, 383 F. Supp. 1164, 1165 (E.D.N.Y. 1974), aff'd without op., 515 F.2d 504 (2d Cir. 1975); Koppell v. Levinc, 347 F. Supp. 456, 459 (E.D.N.Y. 1972); Zucker v. Pamtz, 299 F. Supp. 102, 105 (S.D.N.Y. 1969).

171. 460 F.2d 1355 (7th Cir. 1972).

172. The California Education Code states:

Students of the public schools shall have the right to exercise freedoin of speech and of the press including, but not limited to, the use of bulletin boards, the distribution of printed materials or petitions, the wearing of buttons, badges, and other insignia, and the right of expression in official publications, whether or not such publications or other means of expression are supported financially by the school or by use of school facilities, except that expression shall be prohibited which is obscene, libelous, or slanderous. Also prohibited shall be material which so incites students as to create a clear and present danger of the commission of unlawful acts on school premises or the violation of lawful school regulations, or the substantial disruption of the orderly operation of the school.

Student editors of official school publications shall be responsible for assigning and editing the news, editorial, and feature content of their publieations subject to the limitations of the section. However, it shall be the responsibility of a journalisin advisor or advisors of student publications within each school to supervise the production of the student staff, to maintain professional standards of English and journalism, and to maintain the provisions of this section.

There shall be no prior restraint of material prepared for official school publications except insofar as it violates this section. School officials shall have the burden of showing justification without undue delay prior to any limitation of student expression under this section. 
of a free press by secondary students, continues to remain in effect after Kuhlmeier.

Likewise, various state supreme court decisions indicating that state constitutions can and do grant 1nore expansive free speech rights than those ensured by the federal Constitution also remain in effect. Although these cases have not specifically dealt with the student press, they have been influenced by forum theory in that they view state constitutions as broadening the circumstances and places in which people may speak, as well as what they inay say. ${ }^{173}$

Statutes such as those passed in California and Massachusetts, and recent cases in such states as Pennsylvania, Washington, New Jersey, and California, will offer the best hope for the expansion of student press rights in the years ahead. While the expansion of rights by judicial decisions is often difficult, persons seeking to expand the rights of the officially sponsored student press may approach their local school boards, state boards of education, or legislatures for aid in enacting policies or statutes similar to those in California and Massachusetts. Such legislative enactments would go a long way toward ameliorating the problems

\footnotetext{
"Official school pubhications" refers to material produced by students in the journalism, newspaper, yearbook, or writing classes and distributed to the student body either free or for a fee.

Nothing in this section shall prohibit or prevent any governing board of a school district from adopting otherwise valid rules and regulations relating to oral commnnication by students upon the premises of each school.

Cal. Educ. CodE $\$ 48,907$ (West Snpp. 1988).

The Massachusetts law states:

The right of students to freedom of expression in the public schools of the commonwealth shall not be abridged, provided that such right shall not canse any disruption or disorder within the school. Freedom of expression shall include without limitation, the rights and responsibilities of students, collectively and individually, (a) to express their views through speech and symbols, (b) to write, publish and disseminate their views, (c) to assemble peaceably on school property for the purpose of expressing their opinions. ...

No expression made by students in the exercise of such rights shall be deened to be an expression of school policy and no school officials shall be held responsible in any civil or criminal action for any expression made or published by the students.
}

MASS. GEN. LAwS ANN. ch. 71, $\S 82$ (West 1978). This statute was initially elective for school districts in Massachusetts. See id. $\$ 86$. On July 14, 1988, in response to the Kuhlmeier decision, the Massachusetts legislature made the provision mandatory. See 1988 Mass. Adv. Legis. Serv. ch. 137 (Law. Co-op.). For a history of the Massachusetts response to Kuhlmeier, see Phillips, Legislative Committee Backs Bill to Bar Censoring of School Papers, Boston Globe, Mar. 25, 1988, at 21, col. 1.

173. See Coinunonwealth v. Tate, $495 \mathrm{~Pa} .158,432$ A.2d 1382 (1981) (group protesting presence of FBI director allowed on private college campus); Alderwood Assocs. v. Washington Envtl. Council, 96 Wash. 2d 230, 635 P.2d 108 (1981) (environmentalists permitted to solicit siguatures in privately owned shopping center); State v. Schmid, 84 N.J. 535, 423 A.2d 615 (1980) (state constitution protects right of nonstudent political party members to distribute literature on private university campus), appeal dismissed, 455 U.S. 100 (1982); Robins v. Pruneyard Shopping Center, 23 Cal. 3d 899, 592 P.2d 341, 153 Cal. Rptr. 854 (1979) (opponent of "Zionism" allowed to solicit signatures for petition at privately owned shopping center), aff'd, 447 U.S. 74 (1980). 
created by Kuhlmeier and the resulting loss of free speech in the pluralistic society of the American high school.

\section{CONCLUSION}

The majority of newspapers in America are student newspapers. ${ }^{174}$ The majority of journalists in America are student journalists. ${ }^{175}$ Students participate in journalism for the education, the experience, the opportunity to improve their skills, and the lessons they can learn from the individual stories that they cover and the overall process of newspaper production. Those lessons are best learned in an environment as free as possible from censorship. The Kuhlmeier decision is unquestionably a serious step backward. However, it does not end the debate. As we have argued, many student publications remain unaffected by Kuhlmeier and many more can be protected through state and local mechanisms. Keeping this in inind, there is no reason to beheve that student journahism will not remain a valid and vital force in the years alread, so long as its contributors continue to stand up for what they believe and speak out on the great issues that affect their and their readers' lives.

174. In 1986, the total number of nonstudent newspapers in this country was 1657. EDrToR AND PUBlisher INTERNATIONAL YeARBooK 1987, memo from the publisher. Even assuming that only half of the nation's 31,809 public and private secondary schools have student newspapers, such newspapers far outnumber their nonstudent counterparts. See T. SNYDER, DIGEST OF EDUCATION STATISTICS 1987, at 70 tbl. 59 (1983-1984 figures).

175. Of the $2,787,000$ high-school seniors in $1982,18 \%$, or over 500,000 , worked on the staff of a student publication. T. SNYDER, supra note 174, at 37 tbl. 29,98 tbl. 85 . The full-time work force in news and editorial positions for the entire nonstudent print media has been estimated at only 75,876. D. Weaver \& G. Wilhoit, The American Journalist: A Portrait of U.S. News People AND THEIR WORK 13 tbl. 2.1 (1986). 